\title{
Phase of trial (Justice and Crime Coverage)
}

\section{AUTHOR}

Franziska Oehmer

\section{KEYWORDS}

judicial reporting, court reporting, representativity

\section{BRIEF DESCRIPTION}

The variable "phase of a trial" records whether the phase before, during or after the trial is mainly covered in the reporting (vgl. Haney \& Greene, 2004; Glark, 2015; Strother, 2017). Studies show that the media's focus is mainly on the beginning (when the new information about the case has been introduced) and on the end of the trial and the possible emotional reactions to it, while the main trial is usually not or little covered (Vinson \& Ertter, 2002; Haney \& Greene, 2004).

\section{FIELD OF APPLICATION/THEORETICAL FOUNDATION} The variable serves - among other variables - as an indicator of the representativeness of judicial reporting.

\section{EXAMPLE STUDY}

Haney \& Greene (2004)

\section{INFORMATION ON HANEY \& GREENE (2004)}

Authors: Craig Haney, Susan Greene

Research interest: The study evaluates aspects of newspaper reporting about death penalty cases and capital defendants.

Object of analysis: "representative sample of local, mainstream (i.e., non-"tabloid") newspaper coverage" (134)

Time frame of analysis: not mentioned Codebook: not available

\section{INFO ABOUT VARIABLE}

Variable name/definition: phase of the trial [Phase des Gerichtsprozesses]

Level of analysis: article Operationalization/coding instructions: "Generally, the stage of the trial process at which the article was written was stated explicitly. Otherwise, it was inferred from the content of the article or by comparing the date of the article to others written about the same case.” (p.136)

Values:

- pretrial

- guilt-phase

- penalty

- sentencing-phase

- post trial

Intercoder reliability: Cronbach's alpha of .73 across categories (5 Coder), not mentioned for individual category

\section{REFERENCE}

Clark, T. S., Lax, J. R., \& Rice, D. (2015). Measuring the political salience of Supreme Court cases. Journal of Law and Courts, 3(1), 37-65.

Haney, C. \& Greene, S. (2004). Capital constructions: Newspaper reporting in death penalty cases. Analyses of Social Issues and Public Policy, 4(1), 129-150.

Strother, L. (2017). How expected political and legal impact drive media coverage of Supreme Court cases, Political Communication, 34(4), S. 571-589.

Vinson, C. D., \& Ertter, J. S. (2002). Entertainment or Education: How Do Media Cover the Courts? Harvard International Journal of Press/Politics, 7(4), S. 80-97. 